\title{
ПРОБЛЕМИ ТЕАТРАЛЬНОГО МИСТЕЦТВА ЯК СУСПІЛЬНОГО ХУДОЖНЬОГО ВИРОБНИЦТВА, АБО «МАНУФАКТУРА» В ЕПОХУ ДОМІНУВАННЯ ІНДУСТРІЙ
}

\section{Сергій Безклубенко}

доктор філософських наук, професор, почесний член Національної академії мистецтв України,

Почесний громадянин м. Х'юстона (Техас, США);

e-mail: bezklub@knukim.edu.ua; ORCID: 0000-0002-8709-7129

Київський національний університет культури і мистецтв, Київ, Україна

\begin{abstract}
Анотація
Мета дослідження - з'ясувати особливості функціонування театрального мистецтва як виробничого процесу з огляду на його організаційно-економічну складову на прикладах діяльності театрів США середини 80-х років минулого століття. Методологія дослідження спираєтьсяназагальнонаукові методипізнання: історизм, аналізісинтез, компаративістику. Автор, досліджуючи факти зісторіїтапрактики діяльностітеатральнихколективів, порівнює та аналізує ефективність їх творчості в контексті комерціалізації мистецтва в ринкових умовах соціокультурної реальності. Наукова новизна дослідження полягає в розширенні уявлень про театральне виробництво як художньо-творчий та організаційно-економічний процес. Висновки. 3 огляду на вищезазначене можна засвідчити, що у вітчизняному театрознавстві певною мірою бракує актуальних, цілісних, наскрізних наукових досліджень щодо особливостей організації менеджменту у сфері культури та мистецтв. Проблема трактування художнього виробництва як різновиду виробничої діяльності потребує окремого ґрунтовного наукового осмислення. Досвід діяльності зарубіжних театральних колективів має вивчатись не лише в площині позитивних характеристик, але й з аналітичнокритичним підходом. Загалом, можна засвідчити, що театральне мистецтво з огляду на історично віджилу («мануфактурну») форму організації суспільної праці в процесі підготовки та «виготовлення» кінцевого продукту - «вистави» - приречене на економічну неефективність.
\end{abstract}

Ключові слова: театральне мистецтво; художнє виробництво; американський досвід

\section{Постановка проблеми}

Як ми знаємо з досвіду, мистецький твір - це щось зроблене, коротше - виріб. У цих віддієслівних іменниках (твір, виріб) мовною практикою зафіксована творча, тобто виробнича, природа мистецтва. Інакше кажучи, мистецтво - це виробництво. Більшою чи меншою мірою свідоме чи й зовсім несвідоме, більшою чи меншою мірою нове, досі незнане, чи, навпаки, - наслідування, повторення, відтворення 
вже чогось такого, що є в природі, житті або й у самому мистецтві, але це завжди - творення, творчість, тобто виробництво.

Однак збігом певних не дуже-то щасливих обставин у розумінні та тлумаченні цих понять - мистецтво і виробництво - утворився «катастрофічний» розрив, унаслідок чого слово «виробництво» у зв'язку з поняттям «мистецтво» зазвичай відлякує служителів останнього.

Тимчасом соромитися нема чого. Хіба що тим, хто все ще перебуває у полоні забобонних уявлень, згідно з якими виробництво - це міська, переважно «чиста», порівнюючи із сільською (свинарник, конюшня, телятник, бруд, сморід, кізяки!), праця, зокрема фабрична, заводська, індустріальна. Щоправда, теж не без недоліків: конвеєри, штампи, дим, гази. Та все ж!..

Наукове поняття «виробництво» не має із цим нічого спільного. Бо у науці виробництво витлумачуємо як працю, унаслідок якої (на відміну від добувної та збирацької!) «з'являється», тобто виробляється, новий продукт (такий, якого у такій формі в природі не існує). Відтак мистецтво, «взяте», як говорять філософи, процесуально (як творчість, як творчий процес), постає одним з різновидів виробництва, однією з його «галузей».

Постановка питання про мистецтво як виробництво не нова і наповнена багатьма непорозуміннями. Одне з можливих - звинувачення у вульгарному ототожненні високодуховної діяльності з примітивними саморобками ужиткових речей - щойно було розглянуте й аргументовано, як здається, спростоване. Хоч це не позбавляє від імовірних рецидивів.

\section{Аналіз останніх досліджень і публікацій}

Соціокультурна реальність XXI століття демонструє, як стрімко змінюються обставини, впливаючи на важелі та чинники, що визначають суспільні, партнерські та фінансові відносини, зокрема, у таких сферах, як культура і бізнес. Як зарубіжні, так і вітчизняні науковці та практики різних напрямів мистецької діяльності, аналізуючи історичний досвід, сучасний стан і перспективи розвитку, прагнуть до створення оптимальних умов для творчості колективів.

Від першого свого друкування французькою мовою в Канаді 1993 року наукове видання «Маркетинг у сфері культури та мистецтв» Франсу Кольбера, Жана Нантеля, Білодо та Деніса Річа (2004) набуло надзвичайної популярності й стало бестселером не тільки в Канаді, а й у багатьох країнах світу. Колектив авторів склали визнані світові авторитети - науковці та практики у галузі маркетингу та менеджменту у сфері культури. Аналітично структурований матеріал, що спирається на численні наукові джерела та практичний досвід авторів, дає вичерпну картину сучасного маркетингового процесу у сфері культури: від стратегічного планування та позиціонування підприємства культури й вироблення культурноїпродукції до формування зв' язків зі споживачами, просування на ринок, залучення джерел фінансування й оцінки результатів. Це перше повне та системне видання з питань маркетингу у сфері культури та мистецтв в Україні. 
У 2000 році в Україні вийшла друком монографія відомого у США театрального діяча - імпресаріо та педагога, доктора філософії, професора Стівена Ленглі (2000) «Театральний менеджмент і продюсерство. Американський досвід». Автор, спираючись на театральний, у тому числі і власний, досвід США, під історично-практичним кутом зору осмислює процес підготовки та випуску вистав, форми їх прокату, а також висвітлює проблеми фінансування діяльності театральних колективів різних форм власності й організації в США. Остання глава видання присвячена взаємовідносинам театру з глядачем.

Вивченню та узагальненню організаційних проблем виконавського, зокрема, театрального мистецтва присвячена монографія «Мистецтво і ринок» І. Д. Безгіна (2005) - провідного дослідника питань організації театральної справи як колективної форми художньої творчості. Автор розглядає театр як суб'єкт організованої творчої діяльності та об'єкт управління, акцентуючи увагу на системі міжособистісних стосунків художніх та адміністративних керівників, окреслює шляхи оптимізації організації театральної справи та перспективи розвитку театрального менеджменту.

Маркетинговий підхід як складову менеджменту у сфері культури та мистецтва, а також проблеми бізнес-планування та інвестиційного проєктування розглядають М. П. Переверзєв та Т. В. Косцов (2010), спираючись на досвід Російської Федерації кінця XX - початку XXI століття.

Вітчизняний дослідник проблем сучасної практики організації театральної справи за кордоном - С. С. Васильєв. У його статті «Організаційно-економічні аспекти діяльності театрів лондонського Вест-Енду на сучасному етапі» (Васильєв, 2018) на основі зібраного широкого економіко-статистичного фактологічного матеріалу зроблено узагальнювальний аналіз творчо-організаційної діяльності провідних театрів лондонського Вест-Енду за період з 1998 по 2013 роки.

Аналіз останніх вітчизняних досліджень і публікацій дає змогу дійти висновку, що в сучасному мистецтвознавчому обігу бракує аналітично-критичних, фактологічних, узагальнювальних досліджень зарубіжного та вітчизняного досвіду функціонування мистецтва, зокрема сценічного, як форми виробничої практики.

Мета дослідження - з' ясувати особливості функціонування театрального мистецтва як виробничого процесу з огляду на його організаційно-економічну складову на прикладах діяльності театрів США.

\section{Виклад основного матеріалу}

У Росії 20-х років XX століття багато діячів мистецтва з «революційних» позицій, виступаючи проти «мистецтва для мистецтва», ставили питання про заміну мистецтва «виробництвом гарних речей». Їхні погляди й аргументи були сумарно опубліковані в збірнику статей «Боротьба за реалізм в образотворчому мистецтві 20-х років: матеріали, документи, спогади» (Лебедева ред., 1962).

"Мистецтво, - писав теоретик журналу “ЛЕФ" (Лівий фронт мистецтва) М. Чужак, - як єдиний радісний процес ритмічно організованого ви- 
робництва товаро-цінностей в світлі майбутнього, - ось та програмна тенденція, яка має досягатися кожним комуністом. [...] Мистецтво оскільки воно ще мислиться нами, як тимчасова, надалі до повного розчинення в життя, своєрідна, побудована на використанні емоції, діяльність - є виробництво потрібних класу і людству цінностей (речей)». (Чужак, 1923, с.37-39)

Ось цих «вояків» за «справжнє» мистецтво, які прагнули замінити його виробництвом «свідомо зроблених речей» (Чужак, 1923, с.32), опоненти насмішкувато прозвали «виробничниками» (Чужак, 1923, с. 12-39). I це прозвисько, як пекельний жупел, упродовж сімдесяти років жахало всіх, навіть безневинних у гріху вульгаризму, хто прагнув з'ясувати «взаємини» мистецтва з виробництвом. Сьогодні видається вже очевидним, що примітивізм («вульгарність»), у розумінні виробничого аспекту мистецької діяльності, не може бути перешкодою для наукової постановки питання та належного його з'ясування. Помилка «виробничників» 20-х років полягала в тому, що вони зневажили у мистецтві його пізнавальний та ідеологічний аспекти, переоцінюючи безмірно виробничий. Але раціональному з'ясуванню відношення мистецтва до матеріального виробництва заважало й заважає також протилежне - переоцінка саме ідеологічної, пізнавальної та комунікативної складової і нехтування його процесуальним предметно-речовим, тобто виробничим, аспектом. Тимчасом неупереджене дослідження ролі цього інгредієнта у мистецькій творчості дає змогу пролити додаткове світло на «природу» як мистецтва, так і виробництва.

Визнання за мистецтвом специфіки як засобу пізнання, форми ідеології тощо, усіляке підкреслювання його своєрідності, відстоювання його особливостей при всій їх значущості аж ніяк не може скасувати той факт, що мистецтво все ж виробництво. Це виробництво особливе - «духовне» (на відміну від предметноматеріального), специфічне й поміж «духовних» - художньо-образне (на відміну від науки та педагогіки), але - виробництво.

Із цього випливає, що мистецтво при всій своїй специфічності, будучи все ж виробництвом, має нести в собі всі найважливіші ознаки та властивості, притаманні виробництву взагалі, у тому числі суспільно-організаційні, технікотехнологічні і соціально-економічні. Дослідження технології художнього виробництва (мистецької творчості) допомагає раціонально зрозуміти як генезис художнього, так і соціокультурного явища, закономірності становлення мистецтв, «природу» поетики (творчих методів та художніх стилів). З' ясування організаційних засад мистецької творчості як художнього виробництва допомагає глибше осягнути, зокрема, й передумови як економічного процвітання, так і причини економічних негараздів тих чи тих мистецтв, зокрема театрального.

Річ у тім, що, як виявляється при ближчому розгляді, першорядну роль у вищезазначеній «трійці» (технологія, організація, економіка) відіграє саме техніка (знаряддя виробництва - інструменти, машини та інші пристрої) та технологія (способи її застосування відповідно до їх призначення, тобто їхньої логіки). Саме технологією («логікою техніки») визначаються найбільш ефективні форми суспільної організації праці виробників у процесі виробництва та їх прогресивна на- 
ступність. Як засвідчує історія економічного розвитку людства, основою якого $€$ поступ виробництва, за первісно виключно індивідуальною формою хронологічно йде кооперація (дослівно співпраця групи виробників), затим - мануфактура (ручне виробництво групою працівників спільного продукту), яку наслідує фабрика (колективне виробництво продукції за допомогою машин та механічних пристроїв), і далі - індустрія (масове виробництво уніфікованих продуктів за допомогою автоматизованих та напівавтоматизованих процесів).

Неважко побачити, що мистецтво як галузь суспільного художнього виробництва у своєму історичному перебігу «проходить» такі ж форми суспільної організації праці, що й виробництво будь-якого роду: індивідуальне виробництво (творчість окремого письменника, художника, скульптора); кооперація (творчість танцювальних і музичних ансамблів - хори, оркестри і т. п.); мануфактура (скульптурні та художні майстерні, українські середньовічні «музичні цехи», театральневиробництво); фабрика (кінематограф, радіо, телебачення); індустрія (продукування телесеріалів, комп'ютерна графіка, рекординг, комп'ютерне виробництво мультфільмів, туризм, готельна справа, реклама, мода тощо).

За умов товарного господарства мистецтво як галузь суспільного виробництва втягується в систему панівних економічних відношень: рабовласницьких (архітектура древніх цивілізацій, ужиткові мистецтва, античний театр); феодальних (архітектура, скульптура, живопис, музичне мистецтво, ужиткові мистецтва, перський театр (те'зіє)); капіталістичних (усі традиційні мистецтва, а також нові екранні); соціалістичних (недавній досвід СРСР, країн Східної Європи, сучасний Китаю, В'єтнаму, Північної Кореї (КНДР), Куби).

Мистецтво втягується, включається в систему економічних відносин капіталістичного типу, підпорядковується його загальним законам, наскільки це можливо, зважаючи на специфіку художнього виробництва. Тобто, по-перше, у тій мірі, в якій воно може бути сферою докладання капіталу, i, по-друге, доти, доки воно залишається при цьому мистецтвом. Водночас окремі мистецтва як художні виробництва за певних умов (найголовніша - відповідний досягненням епохи рівень технології!) можуть зберігати роль самостійно й іноді високорентабельно, економічно активного організму (кіно-, телеіндустрія, шоу-бізнес, мистецтво реклами), тимчасом як інші, переважно успадковані історично (зокрема, театр-мануфактура), нездатнідо самостійного, економічно рентабельного функціонування і для свого виживання потребують істотної підтримки від суспільства: цілковито державне утримання, бюджетні дотації (як доповнення до прибутків, самостійно зароблених театральним колективом) та «спонсорство», тобто благодійні пожертвування.

У цьому «пункті» можна вбачити, у чому власне полягає «щастя» та «біда» мистецтв, зокрема театрального. «Щастя» - у тому, що люди майже ніколи добровільно не розлучаються, в будь-якому разі дуже неохоче «розлучаються», з уже винайденими, апробованими, тим паче улюбленими мистецтвами. У крайньому разі останні змінюють свій «статус» в очах споживачів: переходять до ніби нижчого рангу («традиційних»). Зникають, гинуть мистецтва, як правило, лише разом із самими людьми, суспільством, яке спородило це мистецтво. 
Вісник Київського національного університету культури і мистецтв.

Серія: Сценічне мистецтво

У цій природженій «консервативності» мистецтв криється і їхня «біда»: у мінливих динамічних обставинах життя людей вони часто-густо видаються, а то й справді виявляються архаїчним, малопристосованим до нових обставин елементом. Чи не найпереконливішим прикладом тут може слугувати саме «театр-мануфактура» в епоху «фабрик» і домінування індустрій.

Як переконливо засвідчує історія американського театру та перипетії народження американського ж кіно, буржуазія, що опанувала суспільство, вживала відчайдушні (щоб не сказати ґвалтівні!) спроби перетворити театральне виробництво, мануфактурне за «генетикою», на кінофабричне (Эйзенштейн, 1964). Та всі потуги виявились марними!.. Як, до речі, і пророкування занепаду театру у зв'язку з тріумфальним «нашестям» телебачення!..

Незаперечні факти свідчать, що капіталізм використав усе можливе, аби театр-мануфактуруперетворитинатеатр-фабрику. Тількипоявапринциповонових технічних засобів, таких як кінематограф і телебачення (цей синтез технологій радіо, театру та кіно), а разом з ними і принципово нових виробничо-творчих можливостей, поклала край цим несамовитим спробам. Театр не вмер, не щез із появою кіномистецтва та телебачення, як це сталося з мануфактурним виробництвом карет при настанні ери автомобілебудування. Після деякого справді спаду, пов'язаного з винаходом кінематографа, отже, природним відпливом глядачів, відтак - капіталів та творчих сил, встановилася певна динамічна рівновага: кожне з названих художніх виробництв, здійснивши певні вдосконалення, уточнило свої сфери збуту.

Словом, театр «вистояв» і дуже пишається з цього, хоча, правду кажучи, нема особливо чим. За право жити у світі вільних ринкових відносин він заплатив дуже високу ціну. Відступившись від тіла, «золотий диявол» розтліває душу театру. Навіть елементарне «фізичне» його існування підтримується завдяки подачкам. Про це свідчать численні факти.

У березні 1970 року в Лондоні вийшла друком брошура «Театр сьогодні в Англії та в Уельсі», що являла собою доповідь про результати обстеження театрів, організованого Комісією у справах мистецтв Великобританії. Один з рецензентів на цю брошуру писав у тижневику «Оглядач» («The Observer») (22 березня 1970 р.): «Почасти завдяки напливу туристів комерційний театр у Лондоні зводить кінці з кінцями. Кількість комерційних театрів, які працюють у Лондоні, не змінилась за останні 40 років. Але з 130 провінційних театрів, які існували до війни, сьогодні збереглося тільки 33, і багато з них більшу частину року пустують». Серед причин цього занепаду автор називає, зокрема, конкуренцію телебачення та загальне зростання дорожнечі, що призводить до неймовірного підвищення цін на театральні квитки і заразом вимагає нереальних умов експлуатації репертуару: «п'єса має йти в два три рази довше, щоб принести прибуток».

Не набагато ліпші справи й у театрі американському. Наприклад, вистава трупи, що гастролює, зі знаменитого своїми нічними «закладами втіхи» Лас-Вегаса дається в заміському ресторані, починається з 12 ночі. У приміщенні душно і накурено, хоч ресторан і «зелений» - під наметом. Від диму ще густішим здається морок, в який загрузла зала: освітлення лише місцеве - на столику електросві- 
чечка ват на 10-15 та відблиск сліпуче освітленої естради. Над естрадою, десь угорі на антресолях, грає джаз-бенд - оркестрик осіб на 7-8. Назва у нього, за якою і називається вся програма, хоча і можна перекласти українською, однак зрозуміти все ж не легко - «Мільйон доларів у корзині для сміття». На естраду вибігають раптом дівчата, треба гадати, танцівниці; одягнені у флуоресцентні трико, вони вигинаються та вихиляються на всі боки, поступово скидаючи з себе гадючого блиску шмаття, щораз фіксуючи пози, які делікатно заведено називати еротичними, аж поки не залишаються майже без нічого. Потім виходить «розмовник» і розважає публіку теревенями хвилин десять. Слів він не добирає, а говорить усі, які знає, хоч би їх і не друкували в словниках. Далі - «запальний танок» у виконанні «суперзірки» вар'єте Жоржети Данте. Танок італійки з таким гучним ім'ям і справді вогненний, при тому дослівно: дівчина танцює, демонструє головоломні акробатичні трюки зі смолоскипами, які палають. Вона тримає їх у руках, у зубах, ще кілька причеплені, як би це точніше сказати, до всіх вигинів її ледь зодягнутого тіла.

Що було далі, дивитися вже не захотілося. Дорогою до готелю, це було в X'юстоні, штат Техас, вдалося зазирнути на кілька хвилин у салун - традиційно улюблене місце дозвілля американців. Це тісні, душні, прокурені і просякнуті горілчаними парами споруди на зразок колишніх наших сільських «амбарів». На заяложених лавках, мов нанизані на «шампур» шашлики, сидять глядачі та глядачки; п'є хто пиво, хто віскі. Розмовляють, цілуються, сміються, а на підмостках з удаваною невимушеністю патякає черговий сквернослов, або корчиться в пароксизмах «танцю» чергова герл.

Такого сорту сценічним продуктом годують у США тих, хто належить, за панівною там класифікацією, до низів - nitherclassmen. А чим пригощають середняків - middlclassmen?

Ось один з бродвейських мюзиклів, що здобув національну нагороду - Пулітцерівську премію, протягом кількох (чи не десяти) сезонів визнавався найпопулярнішим, - «A Chorus Line» («Кардебалет», прем'єра відбулась 16 квітня 1975 року в Громадському театрі Джозефа Паппа (Joseph Papp's Public Theatre)). Дослівно «лінія хору», а в цьому разі - зібрання всієї трупи. Сюжет вистави невигадливий: хтось, режисер чи продюсер, вирішив здійснити якусь музичну виставу і набирає для цього трупу. Усіх, хто прийшов «на кастинг», він шикує в одну лінію (звідси назва) і знайомиться з ними, називаючи кожного зокрема. Глядачі стають свідками цього знайомства. Кожний «претендент» на місце актора в трупі за викликом «режисера», якого грає актор, що сидить у залі серед глядачів, розказує «свою житейську історію» і показує, що він може робити в театрі: співає або танцює, декламує або грає на якомусь інструменті. «Історії» виявляються найрізноманітнішими - зворушливими і смішними, сповненими відчаю і надії, і саме вони захоплюють глядачів, несучи в собі певне смислове навантаження й ідейний пафос; увага глядачів своєчасно «освіжується», відновлюється за допомогою музично-пісенних дивертисментів. Вистава вибудувана так, щоб не перевтомлювати відвідувачів проблемами, яких у них і без театру доста в повсякденному житті, але, показавши їх настільки, наскільки необхідно, щоб гля- 
дачі могли переконатися ще раз, що в кожного своє горе, щоб дати можливість їм розвіятися, розслабитися, відпочити, помріяти, відновити в душі надію, яка пригасає, на те, що колись та може усміхнеться щастя. Не буде зайвим відзначити, що еротиці та сексу в цьому відводиться «чільне» місце.

На фасаді приміщення вашингтонського театру «Арена-стейдж» ("Arena Stage") розвішані велетенські щити, густо списані прізвищами. Це так звані applaudissements - оплески, дяка за пожертвування. Залежно від суми пожертвування - і честь. Спершу йдуть імена особливо «щедрих», розмір внесків яких навіть не вказують; їх іменують «почесними продюсерами», «почесними режисерами», далі йдуть «благодійники», «спонсори», «донори», «контрибутори»; за ними - «члени гільдії», «друзі», «передплатники», суму внеску яких уже зазначають. Прізвища «благодійників» друкують також у театральних програмках.

Така повсюдна практика. Навіть театри Х'юстона, що хизуються своїм «проспериті», який постійно зростає, змушені жебрати. Як зазначають у рекламноагітаційних брошурах театрів, тим, хто жертвує, за це гарантуються привілеї: хто дасть милостиню в 100 доларів, прізвища надрукують у трьох випусках театральної програмки та зарезервують квиток на «весняний концерт оперних співаків»; хто подасть 500 доларів - те ж, що й попереднім, та ще й запросять на генеральну репетицію, поведуть на екскурсію в залаштункову частину і гарантують квитки на «спеціальні заходи»; за подання в 1000 доларів - те ж, що й попереднім, та ще й «право участі в щорічному урочистому обіді в товаристві артистів з танцями» і запрошення супроводити театр у гастрольній поїздці. Ну, а тим, хто пожертвує п'ять і більше тисяч доларів, крім усього того, гарантуються «привітання і компліменти» в театральних програмках і листках-лібрето, а також запрошення на «спеціальні коктейль-прийоми та обіди з артистами». Подарунками, роз' яснює дирекція X'юстонської гранд-опери, можуть бути не тільки асигнації, чеки, готівка, а й речі, наприклад «твори мистецтва, антикваріат, ювелірні вироби, цінні книги» і навіть... страховки на власне життя.

Не ліпші справи і в театрах Сан-Франциско. «Підтримуйте сан-франциську опеpy! - волає, надрукований червоним (мов SOS!) заголовок замітки, опублікованої в спеціальному, ювілейному для театру випуску буклета про цю оперу, в якому зазначено:

«Кожного року Сан-Франциський оперний театр змушений роздобувати кошти, яких бракує для збалансування бюджету. Доходи від продажу квитків навіть при повному використанні всіх можливостей приміщення становлять трохи більше 60 \% витрат - це значно вищий показник, ніж у переважної більшості великих національних та зарубіжних театрів. Однак нам належить роздобути решту 40 \% за допомогою здійснення різних спеціальних "програм підтримки", включаючи гарантії, річні відрахування від різних фондів, надходження від пожертвувателів, муніципальних і федеральних дотацій і окремих поручителів за постановку».

Криком кричить зі своїх афіш і Американська консерваторія-театр (American Conservatory Theater), що вважає себе (і не без підстав!) однією з найкращих у країні: 
«А.С.Т. потребує вас! Американська консерваторія-театр приречена до найтяжчих випробувань через найменшу порівняно з будь-яким іншим театром дотацію з національного фонду пожертвувань на мистецтво. Федеральний уряд повинен вирівняти і збільшити дотацію з цього фонду! Але потрібно ще дуже багато. Половину необхідних на цей рік коштів уже зібрано, однак решту мусимо роздобути до 31 травня. Допоможіть пережити важкі випробування - пожертвуйте для Американської консерваторії-театру ЗАРАЗ!»

Особливо уклінно жебрає американський театр у можновладців - некоронованих королів Америки - Фордів, Рокфеллерів, Меллонів, інших багатіїв.

На фактичному утриманні фінансових і промислових верховод перебуває і Сан-Франциський театр балету - від пуантів до шпильок у косах танцівниць. Створений у 1932 році на базі однієї з перших у США постійних труп цей театр мало не загинув у 1974 році, коли в його бюджеті виявився дефіцит майже мільйона доларів. У ролі «батьків-благодійників», які врятували збанкрутілий театр від смерті, виступили, ясна річ, від імені некоронованих королів Америки місцеві «батьки». Театр вижив. Про те, якою ціною, можна лише здогадуватися з усталених відтоді прийомів зваблювання «глядачів» - друзів театру.

Ось буклет-реклама Сан-Франциського балету. На примітному місці обкладинки, там, де у нас колись було неодмінне «Пролетарі усіх країн єднайтеся!», повідомлення: «Ця брошура зроблена коштом покровителів». Зміст цієї брошури - відверто зазивальний: фотографії танцівниць і танцівників у «найпривабливіших» позах, щоб впали в око насамперед статеві достоїнства актора. Сфотографовані актори і в роботі, під час вистави чи репетиції, і в домашній обстановці, і в невимушеній - під час дозвілля, у різному одязі та майже без... Під фотографіями текстівки, що, за задумом, мають передавати сказане тією чи тією особою: дотепи, девізи, афоризми. Ясна річ, буклет розпочинається списком патронів, а потім уже - фото прими-балерини Дамари Беннет. «Люди здаються мені, - нібито каже вона, - тим більш відкритими, чим менше на них одягу... Моя б воля я хверцювала б голісінькою, лише з квіткою у косах». Інша буцімто, навпаки, має пристрасть до вбрання: «Моя слабкість - виряджатися з усякого приводу, а особливо - без приводу». Третя ще в іншому стилі саморекламується: «Я вірю, що повинна зосередити основну енергію на балеті, поки залишаюся танцівницею. Пізніше я зможу присвятити себе цілком іншій кар'єрі - повноцінної дружини й матері». Четверта - їй, так би мовити, у пандан: «Мій улюблений вираз: перш ніж ви зустрінете прекрасного царевича, вам доведеться перецілувати чимало жаб».

Комерційний директор «Нью-Йорк сіті балет» («New York City Ballet» (NYCB)) Тофен Фер (Thofen Fer), трохи відкриваючи завісу, що приховує від очей непосвячених їхні залаштункові шоу для «благодійників», у бесіді зазначала:

«Громадська діяльність будь-якого роду виробила свої прийоми роздобування грошей, які стали класичними, і керівництво “Нью-Йорк сіті балет" володіє деякими з них. Головний - знамениті осінні та весінні гала-концерти в травні, коли жінки приходять у вечірніх сукнях, а чо- 
ловіки - у смокінгах, щоби покружляти під музику вальсу на мармуровій підлозі головного фойє театру».

Це для всіх охочих... хто спроможний купити квиток, який коштує казково дорого, як і бокал шампанського - сотні і сотні доларів... Крім того, так званий «спеціальний комітет» з організації так званих «спеціальних заходів» спрямовує свої зусилля на те, щоб «залучити друзів театру до більш коротких, інтимних стосунків з керівництвом театру, музикантами і танцівниками». Для цих людей у приміщенні театру обладнана особлива «зелена кімната», розрахована на 75 осіб для коктейлю і на 36 - для обіду. При цій кімнаті «є добре устаткована кухня і відлюдна ванна кімната». «За плату в 1000 доларів ми можемо сервірувати цю кімнату для коктейлю або закуски під час антракту чи для вечері - тих, хто побажає зайняти її на ніч у день балетної вистави», - розповідала Тофен Фер.

От такі, сказати б, «шоу». На сцені і по той бік неї.

«Чи вільні ви від вашого буржуазного видавця, пане письменнику? - свого часу ставив питання перед літераторами, а також художниками й діячами сцени ще тоді «недекомунізований» критик, - від вашої буржуазної публіки, яка вимагає від вас порнографії в рамках і картинах, проституції у вигляді "доповнення" до “святого" сценічного мистецтва?» (Ленин, 1968, с.103-104).

Уся, так би мовити, «королівська рать» некоронованих королів Америки зі шкіри пнеться, аби подібні питання навіть не навідувалися до голів талановитих людей. Та все ж багато хто з них, незважаючи на те, що їх безперервно труять наркотиками ілюзій щодо так званої свободи самовираження, не можуть не відчути, що вся ця «свобода творчості» $€$ «лише замаскована (або така, що лицемірно маскується) залежність від грошового мішка, від підкупу, від утримання» (Ленин, 1968, с. 103). «У Європі і Росії загальна турбота про мистецтво рішуче більш значна, чим тут, в Америці, - публічно заявляв Джон Донах'ю (John Clark Donahue), засновник і керівник театру для дітей (Children's Theatre Company) у Міннеаполісі (у той час єдиного в США!). - Деякі європейські країни витрачають у розрахунку на душу населення в сто разів більше на розвиток мистецтва, ніж США. Сполучені Штати - фактично єдина країна у світі, яка не виявляє істотної громадськоїпідтримки розвитку мистецтва. Жителі Східної Європи подають приклад решті світу в підтримці театрів для дітей... Вони розуміють, що майбутнє їх країн залежить від виховання і розвитку творчих здібностей їхньої молоді».

Що не все благополучно в цій сфері, змушені бувають визнати, керуючись, звісно, своїми політиканськими міркуваннями, навіть окремі «боси». Зафіксовано принаймні один такий безпрецедентний випадок: виступ губернатора одного зі штатів, цілком присвячений питанням розвитку культури і мистецтва. Вихваляючи на всі боки прогрес у цій сфері, губернатор, однак, змушений був усе ж констатувати:

«Хочгромадяни, бізнесмени іпредставникигромадських фондів вкладають свої гроші і таланти в мистецтва більше, ніж у будь-яку іншу сферу, за останні десять років ці фонди у штаті залишаються мізерни-

\footnotetext{
${ }^{4}$ У джерелі, мабуть, помилка; за змістом - «в романах» (С. Б.).
} 
ми навіть у порівнянні з іншими штатами. Наприклад, хоч ми з такою гордістю виставляємо розвиток у нас мистецтва, на цю справу торік було витрачено всього лише 13 центів на душу населення, тимчасом як у штаті Юта - у два з лишком рази більше, в Колорадо - 90 центів, у штаті Нью-Йорк - майже 2 долари на голову».

Чому такі благодіяння падають на голови жителям Нью-Йорка, здогадатися не важко: саме тут «лежать» головні гроші США і саме тут розташований головний корпус творчої інтелігенції країни, і саме тут - найгустіший споживач (18 мільйонів населення лише в самому місті). Крім федерального, з якого щастить ньюйоркцям уривати трохи більшу, ніж інші, дещицю, тут є і свій міський «фонд пожертвувань на розвиток мистецтва». Розподілом його відає спеціально утворений орган - «Рада щодо мистецтва». Так цей орган іменується, насправді ж це не дуже навіть замаскований орган цензури, орган жорсткого політичного контролю з боку (точніше сказати, зверху!) тих, хто жертвує ці долари.

Судіть самі: для того, щоб згадана «Рада» взяла до розгляду клопотання про виділення субсидії, пошукувачу необхідно письмово відповісти на численні питання. Сам лише перелік їх займає 10 сторінок машинопису. Інструкція ж про те, як відповідати, - 50 сторінок. І це не просто таке собі «бюрократичне гачкотворство». Найважливіше та найбільше місце відводиться питанням на зразок: «мета і діяльність організації», «дати повне описання програми або діяльності, для яких запитуються гроші із фонду» і т. п.

Наукова новизна. Отже, спираючись на практичний досвід діяльності театральних колективів США останньої чверті минулого століття, можна розширити уявлення про театральне виробництво як художньо-творчий та організаційноекономічний процес.

\section{Висновки}

З огляду на вищезазначене можна засвідчити, що у вітчизняному театрознавстві певною мірою бракує актуальних цілісних наскрізних наукових досліджень щодо особливостей організації менеджменту у сфері культури та мистецтв. Проблема трактування художнього виробництва як різновиду виробничої діяльності потребує окремого ґрунтовного наукового осмислення. Досвід діяльності зарубіжних театральних колективів має вивчатись не лише у площині позитивних характеристик, але й з аналітично-критичним підходом. Загалом, можна засвідчити, що театральне мистецтво з огляду на історично віджилу («мануфактурну») форму організації суспільної праці в процесі підготовки та «виготовлення» кінцевого продукту - «вистави» - приречене на економічну неефективність.

\section{СПИСОК ПОСИЛАНЬ}

Безгін, І.Д., 2005. Мистецтво і ринок: нариси. Київ: Компас.

Васильєв, С.С., 2018. Організаційно-економічні аспекти діяльності театрів лондонського Вест-Енду на сучасному етапі. Вісник Київського національного університету культури 
і мистецтв. Серія: Сценічне мистецтво, 1, с.90-103. https://doi.org/10.31866/2616759x.1.2018.144962.

Кольбер, Ф., Нантель, Ж., Білодо, С. та Річ, Дж., 2004. Маркетинг у сфері культури та мистецтв. Переклад з англійської. Львів: Кальварія.

Лебедева, П.И. ред., 1962. Борьба за реализм в искусстве 20-хгодов: материалы, документы, воспоминания. Москва: Советский художник.

Ленглі, С., 2000. Театральний менеджмент і продюсерство. Американський досвід. Переклад з англійської. Київ: Компас.

Ленин, В.И., 1968. Партийная организация и партийная литература. В: Полное собрание сочинений. Москва: Издательство политической литературы. Т. 12, с.99-105.

ЛЕФ: Журнал Левого фронта искусств, 1923. Москва: Государственное издательство, 1.

Переверзев, М.П. и Косцов, Т.В., 2010. Менеджмент в сфере культуры и искусства. Москва: ИНФРА-М.

Чужак Н.Ф., 1923. Под знаком жизнестроения (опыт осознания искусства дня). ЛЕФ, 1, с.12-39.

Эйзенштейн, С.М., 1964. Избранные произведения. Москва: Искусство, Т. 2, с.156-188.

\section{REFERENCES}

Bezghin, I.D., 2005. Mystetstvo i rynok: narysy [Art and the market: essays]. Kyiv: Kompas.

Chuzhak N.F., 1923. Pod znakom zhiznestroeniia (opyt osoznaniia iskusstva dnia) [Under the sign of life-building (the experience of comprehending the art of the day)]. LEF, 1, pp.12-39.

Colbert, F., Nantel, J., Bilodeau, S. and Rich, JD., 2004. Marketynh u sferi kultury ta mystetstv [Marketing culture and the arts]. Translated from English. Lviv: Kalvariia.

Eizenshtein, S.M., 1964. Izbrannye proizvedeniia [Selected works]. Moscow: Iskusstvo, T. 2, pp.156-188.

Langley, S., 2000. Teatralnyi menedzhment $i$ prodiuserstvo. Amerykanskyi dosvid [Theatre Management and Production in America]. Translated from English. Kyiv: Kompas.

Lebedeva, P.I. ed., 1962. Borba za realizm v iskusstve 20-kh godov: materialy, dokumenty, vospominaniia [Struggle for realism in the art of the 1920s: materials, documents, memoirs]. Moscow: Sovetskii khudozhnik.

LEF: Zhurnal Levogo fronta iskusstv [LEF: Journal of the Left Front of the Arts], 1923. Moscow: Gosudarstvennoe izdatelstvo, 1.

Lenin, V.I., 1968. Partiinaia organizatciia i partiinaia literatura [Party organization and party literature]. In: Polnoe sobranie sochinenii [Complete Works]. Moscow: Izdatelstvo politicheskoi literatury. T. 12, pp.99-105.

Pereverzev, M.P. and Kostcov, T.V., 2010. Menedzhment $v$ sfere kultury i iskusstva [Management in the field of culture and art]. Moscow: INFRA-M.

Vasyliev, S.S., 2018. Orhanizatsiino-ekonomichni aspekty diialnosti teatriv londonskoho VestEndu na suchasnomu etapi [Organizational and economic aspects of the theaters of the London West End at the present stage]. Bulletin of Kyiv National University of Culture and Arts. Series in Stage Art, 1, pp.90-103. https://doi.org/10.31866/2616-759x.1.2018.144962. 


\section{ПРОБЛЕМЫ ТЕАТРАЛЬНОГО ИСКУССТВА КАК ОБЩЕСТВЕННОГО ХУДОЖЕСТВЕННОГО ПРОИЗВОДСТВА, ИЛИ «МАНУФАКТУРА» В ЭПОХУ ДОМИНИРОВАНИЯ ИНДУСТРИЙ}

\section{Сергей Безклубенко}

доктор философских наук, профессор, почетный член Национальной академии искусств Украины, Почетный гражданин г. Хьюстон (Техас, США);

e-mail: bezklub@knukim.edu.ua; ORCID: 0000-0002-8709-7129

Киевский национальный университет культуры и искусств, Киев, Украина

\section{Аннотация}

Цель исследования - выяснить особенности функционирования театрального искусства как производственного процесса с учетом его организационно-экономической составляющей на примерах деятельности театров США середины 80-х годов прошлого века. Методология исследования опирается на общенаучные методы познания: историзм, анализ и синтез, компаративистику. Автор, исследуя факты из истории и практики деятельности театральных коллективов, сравнивает и анализирует эффективность их творчества в контексте коммерциализации искусства в рыночных условиях социокультурной реальности. Научная новизна исследования заключается в расширении представлений о театральном производстве как художественно-творческом и организационно-экономическом процессе. Выводы. Учитывая вышесказанное, можно говорить, что в отечественном театроведении в определенной степени не хватает актуальных, целостных, сквозных научных исследований об особенностях организации менеджмента в сфере культуры и искусств. Проблема трактовки художественного производства как разновидности производственной деятельности требует отдельного обстоятельного научного осмысления. Опыт деятельности зарубежных театральных коллективов должен изучаться не только в плоскости положительных характеристик, но и с аналитически-критическим подходом. В общем, можно говорить, что театральное искусство, учитывая исторически отжившую («мануфактурную») форму организации общественного труда в процессе подготовки и «изготовления» конечного продукта - «представления», обречено на экономическую неэффективность.

Ключевые слова: театральное искусство; художественное производство; американский опыт 


\title{
PROBLEMS OF THEATER ART AS PUBLIC ART PRODUCTION OR "MANUFACTURE" IN THE AGE OF INDUSTRIAL DOMINATION
}

\section{Serhii Bezklubenko}

Doctor of Philosophy, Professor, Honorary Member of the National Academy of Arts of Ukraine, Honorary Citizen of Houston (Texas, USA); e-mail: bezklub@knukim.edu.ua; ORCID: 0000-0002-8709-7129

Kyiv National University of Culture and Arts, Kyiv, Ukraine

\begin{abstract}
The purpose of the study is to find out the features of the functioning of theatrical art as a production process in view of its organizational and economic component on the examples of the theaters of the United States in the mid-80s of last century. The research methodology is based on general scientific methods of cognition: historicism, analysis and synthesis, comparative studies. The author, exploring the facts of the history and practice of theater groups, compares and analyzes the effectiveness of their work in the context of commercialization of art in the market conditions of socio-cultural reality. The scientific novelty of the study lies in the expansion of ideas about theatrical production as an artistic and creative and organizational and economic process. Conclusions. In view of the above, we can say that in domestic theater studies to some extent lacks relevant, holistic, cross-cutting research on the peculiarities of the management organization in the field of culture and arts. The problem of artistic production interpretation as a kind of production activity requires a separate thorough scientific understanding. The experience of foreign theater groups should be studied not only in terms of positive characteristics, but also with an analytical-critical approach. In general, we can say that theatrical art, given the historically outdated ("manufactory") form of social work organization in the process of preparation and "production" of the final product "performance" is doomed to economic inefficiency.
\end{abstract}

Keywords: theater art; art production; American experience 